\title{
SEROTYPING OF CANDIDA ALBICANS ISOLATED FROM CLINICAL SPECIMENS
}

\author{
MARIA L. MARTINEZ BATISTA; GERARDO MARTINEZ MACHIN; CARLOS FERNANDEZ \\ ANDREU \& ALINA LLOP HERNANDEZ
}

Laboratorio de Micología, Instituto de Medicina Tropical "Pedro Kouri", Apdo Postal 601, Ciudad de la Habana, Cuba

$A$ specific antiserum to Candida albicans serotype $A$ was prepared adsorbing a total antiserum with Candida albicans serotype $B$ cells. This specific antiserum was used for serotyping $\mathrm{C}$. albicans strains obtained from patients in different hospitals of Havana City, Cuba. Two hundred strains $(95.2 \%)$ were serotype $A$, the remaining $10(4.8 \%)$ were serotype B. Results were also correlated with strains isolated from the specimen origin, sex and race of the patient. The usefulness of this specific antiserum to determine $\mathrm{C}$. albicans serotypes and its therapeutic value are pointed out.

Key words: Candida albicans - candidiasis - serotypes

Candidiasis is the most frequent opportunistic mycosis of man found in medical practice. It appears generally as a localized mycosis, although it may also be systemic. It shows an acute or sub-acute course, and affects the skin, nails, mucosa, bronchi and lungs. It rarely causes endocarditis, meningitis or septicaemia. It is caused by species of the genus Candida, particularly, C. albicans (Rippon, 1982; Walsh \& Pizzo, 1988).

It has been pointed out that some strains of C. albicans have different antigenic structures and unlike behaviour in agglutination reactions (Siqueira et al., 1980).

It was not until 1961 that Hasenclever \& Mitchell, based on the agglutinative properties of the antisera prepared from different $C$. albicans strains, divided this species into two serotypes (serotypes A and B).

The existence of the serotypes is known to be related with differences in the structure of polysaccharides from the cell wall. Such differences may possibly be given by the size of the alpha-D-mannopyranosil residues of the respective polysaccharides, being greater that of serotype A (Siqueira et al., 1980; Kogan et al., 1988). More recently, immunoblotting and im-

Received September 15, 1989. Accepted November $21,1989$. munofluorescence techniques using monoclonal and polyclonal antibodies have confirmed the composition of $C$. albicans cell wall (Casanova et al., 1989). Some authors also relate the predominant serotype with race or sex of the patients (Closets et al., 1986).

Another differences between serotypes A and $\mathrm{B}$ is their behaviour against 5-fluorocytosine (5-FC) (Drouhet et al., 1975; Perrot et al., 1977). 5-FC and amphotericin B are considered the drugs of choice for treatment of systemic candidiasis. Taking this into account, we deem it important to obtain a type $\mathrm{A}$ anti- $C$ albicans specific antiserum useful for serotyping and whereby we could be able to know the most commonly found $C$. albicans serotype in the studied strains, as well as its possible relationship with sex, race and isolation site.

\section{MATERIALS AND METHODS}

Control strains $-C$ albicans $3153 \mathrm{~A}$ and $3156 \mathrm{~B}$, from the Pasteur Institute, Paris.

Specific antiserum - A total antiserum was obtained by inoculation of serotype-A $C$. albicans in rabbits. This antiserum was adsorbed by mixing equal parts of it with a cell suspension from a 24-hour-old serotype-B $C$. albicans culture, inactivated at $60^{\circ} \mathrm{C}$ until saturation. The specific antiserum was obtained when taking the supernatant apart after centrifugation at $5000 \mathrm{rpm}$ for $20 \mathrm{~min}$. Its specificity was 
assessed by mixing equal parts of it with a $3 \times 10^{7} \mathrm{cell} / \mathrm{ml}$ suspension of $C$. albicans control strains (Drouhet et al., 1975).

Specimens - Consisted of 210 C. albicans strains isolated from patients attending hospitals of Havana City during the months of JanuaryJuly, 1988.

These strains were sent to the National Reference Laboratory of the Instituto de Medicina Tropical "Pedro Kouri" for identifications. All strains were classified according to the localization site of lesions, the race and sex of patients.

Slide agglutination technique - A $3 \times 10^{7}$ cell $/ \mathrm{ml}$ suspension was prepared from each strain in phenolated saline solution, resulting in an optical density (O. D.) of $0.250(525 \mathrm{~nm})$. This $O$. D. value served to assess the concentration of cell suspensions in strains to be studied.

Three specific antiserum dilutions $(1: 2 ; 1: 4$; $1: 8)$ were assessed in order to obtain the optimum work dilution. If mixing one drop of the suspension from the study strain with one drop of the specific antiserum results in the formation of clusters in a 3-second interval, the microorganism was classified as serotype A. If the suspension remained homogeneous, with no clusters, it was classified as serotype B (Hasenclever \& Mitchel, 1961).

The chi ${ }^{2}$ method was used for comparisons.

\section{RESULTS}

The specific antiserum was used at the $1: 4$ dilution. Of the 210 strains studied, 200 re- sulted to be of serotype A and 10 of serotype B ( 95.2 and $4.8 \%$ respectively). All strains were obtained from different patients, and there was no coincidence of both serotypes in the same clinical specimen.

In Havana, serotype A was predominant in both sexes as well as in both races $(p \leqslant 0.05)$ (Table I).

Serotype A strains were predominant in isolates from the genitalia and the urinary tract $(97.8 \%)$, while serotype B was more commonly found in strains from skin lesions and surgical wounds $(7.1 \%)$ (Table II). Sixty nine of the studied $C$. albicans strains were obtained from vaginal exudates. Of these, 67 strains $(97.1 \%)$ were of serotype A and 2(2.9\%) of serotype B.

\section{DISCUSSION}

To identify $C$. albicans serotypes, the slide agglutination and immunofluorescence tests have been used (Hasenclever \& Mitchell, 1963; Drouhet et al., 1975; Auger et al., 1979; Repentygny, 1984; Delga et al., 1985). The slide agglutination test was chosen because it is simple, economic and easy to perform in any laboratory.

The coexistence of serotypes $A$ and $B$ in one specimen is exceptional, although both serotypes can be isolated from different anatomic sites in one patient (Hasenclever \& Mitchell, 1963; Auger et al., 1979; Auger, 1983). The strains used in this study were obtained from different patients, and no coincidence of both serotypes was found in one specimen.

TABLE I

Distribution of specimens by serotype of Candida albicans and race and sex of patients

\begin{tabular}{|c|c|c|c|c|c|}
\hline \multirow{2}{*}{ Serotype } & \multicolumn{2}{|c|}{ Sex } & \multicolumn{2}{|c|}{ Race } & \multirow{2}{*}{ Total } \\
\hline & $M(\%)$ & $F(\%)$ & $\mathrm{W}(\%)$ & $\mathrm{B}(\%)$ & \\
\hline $\mathbf{A}$ & $64(91.4)$ & $136(97.1)$ & $118(95.9)$ & $82(94.3)$ & $200(95.2)$ \\
\hline $\mathbf{B}$ & $6(8.6)$ & $4 \quad(2.9)$ & $5 \quad(4.1)$ & $5 \quad(5.7)$ & $10 \quad(4.8)$ \\
\hline Total & 70 & 140 & 123 & 87 & 210 \\
\hline
\end{tabular}

M: male; F : female; W: white; $B$ :black. 


\section{TABLE II}

Distribution of isolated strains of Candida albicans by serotype and localization site of lesions

\begin{tabular}{lccc}
\hline \multicolumn{1}{c}{$\begin{array}{c}\text { Site } \\
\text { of } \\
\text { isolation }\end{array}$} & A (\%) & B $(\%)$ & Total \\
\cline { 2 - 3 } & $19(95)$ & $1(5)$ & 20 \\
\hline $\begin{array}{l}\text { Sputum, mouth } \\
\begin{array}{l}\text { Skin lesions, } \\
\text { surgical wounds }\end{array}\end{array}$ & $79(92.9)$ & $6(7.1)$ & 85 \\
$\begin{array}{l}\text { Genitalia, genito- } \\
\text { urinary tract }\end{array}$ & $91(97.8)$ & $2(2.2)$ & 93 \\
Others & $11(91.7)$ & $1(8.3)$ & 12 \\
\hline
\end{tabular}

Similar studies by Drouhet et al. (1975), Perrot et al. (1977) and Closets et al. (1986) in Europe also showed predominance of serotype A (96, 90 and $96.1 \%$ respectively). Much lower percentages were reported for serotype $A$ in the United States $(67.7 \%)$ by Hasenclever \& Mitchell (1963), and in Canada (74.3\%) by Auger et al. (1979), found a $74.3 \%$ of this serotype.

Other reports (Hasenclever \& Mitchell, 1961; García \& Siqueira, 1988) show a higher isolation of serotype B in blacks than in whites. Results from this study (Table I) show predominance of serotype $A$, irrespective of the race.

Hasenclever \& Mitchell (1963) reported a higher number of serotype A strains from the nasopharyngeal region, and of serotype $B$ more commonly isolated in the vagina. Of the 55 strains isolated in the vagina, $60 \%$ were of serotype B. In 1988, García \& Siqueira studied 104 specimens of vaginal secretions and found that of the $58 \mathrm{C}$. albicans strains, $86.2 \%$ were of serotype A and $13.8 \%$ of serotype B. Likewise, the finding of $C$. albicans in the vagina showed predominance of serotype A $(97.1 \%)$ in the studied specimens.

The establishment of the predominant C. albicans serotype in a given region or area is of therapeutic interest. Serotype A is known to be sensitive to 5-FC, while serotype $B$ is usually resistant to this drug (Closets et al., 1986; Galgiani et al., 1987). If the circulating serotype in a given region is serotype $\mathbf{A}$, the abovementioned drug could be used in severe cases that require immediate treatment and whose general status or renal function does not allow the use of amphotericin-B (which is not unusual in patients with disseminated candidiasis) (Gerald \& Bodey, 1984). If the isolated strain and the specific antiserum are available, it will then be possible to know the serotype in question and rapidly infer the possible sensitivity of the strain to 5-FC. This is so because serotyping may be performed in less than 2 hours and without any special technique. If the specific antiserum is available, the serotyping may be performed in any laboratory.

\section{ACKOWLEDGEMENTS}

To Prof. F. Mariat, from the Pasteur Institut of Paris, who kindly donated the reference strains that made this study possible.

\section{REFERENCES}

AUGER, P., 1983. Interactions of serotypes A and B of Candida albicans in mice. Sabouraudia, 21 . 173-178.

AUGER, P.; DUMAS, C. \& JOLY, J., 1979. A study of 666 strains of Candida albicans: correlation between serotype and susceptibility to 5-fluorocytosine. J. Infect. Dis., 135:590-594.

CASANOVA, M.; GIL, M. L.; CARDEN̄OSO, L.; MARTINEZ, J. P. \& SENTANDREU, R., 1989. Identification of wall-specific antigens synthesized during germ tube formation by Candida albicans. Infect. Immun., 57: 262-271.

CLOSETS, F.; LEREBOURG, P. ; BRACQUEMONT, E. \& FOURNON, M., 1986. Etude de la biologie des souches de Candida albicans par sérotype, a partir de souches isolées au C. H. R. de Tours en 1985. Incidences épidémiologiques. Bull. Soc. Fr. Mycol. Med., 15:337-342.

DELGA, J. M.; IBRAHIM-GRANET, O.; VELEZARANGO, H. \& DROUHET, E., 1985. Sérotypes A et $\mathrm{B}$ de Candida albicans. Etude comparative par électrophorese et immunoempreinte. Bull. Soc. Fr. Mycol. Med., 14:119-126.

DROUHET, E.; MERCIER-SOUCY, L. \& MONTPAISIR, S., 1975. Sensibilité et résistance des levures pathogénes au x 5 -fluoropirimidines. I. Relation entre les phénotypes de résistance a la 5-fluorocitosine, le sérotype de Candida albicans et l'ecologie de differentes espéces de Candida d'origene humaine. Ann. Microbio., 126B: 25-39.

GALGIANI, J. N.; REISER, J. ; BRASS, C.; ESPINELINGROFF, A. ; GORDON, M. A. \& KERKERING, T. M., 1987. Comparison of relative susceptibilities of Candida species to three antifungal agents as determined by unstandardized methods. Antimicrob. Agents Chemother., 31: 1343-1347.

GARCIA, A. L. \& SIQUEIRA, A. M., 1988. Isolamento, identificação e serotipagem de Candida albicans a partir de secreção vaginal. Rev. Inst. Med. trop. Säo Paulo, 30:270-273.

GERALD, P. \& BODEY, M. D., 1984. Candidiasis in cancer patients. Amer. J. Med., 77: 13-19. 
HASENCLEVER, H. F. \& MITCHELL, W. O., 1961. Antigenic studies of Candida. I. Observation of two antigenic groups in Candida albicans. J. Bact., 82: 570-573.

HASENCLEVER, H. F. \& MITCHELL, W. O., 1963. Antigenic studies of Candida. IV. The relationship of the antigenic groups of Candida albicans to their isolation from various clinical specimens. Sabouraudia, 2: 201-204.

KOGAN, G.; PAVLIAK, V. \& MASLER, L., 1988. Structural studies of mannan from the cell walls of the pathogenic yeasts Candida albicans serotypes $\mathbf{A}$ and $\mathrm{B}$ and Candida parapsilosis. Carbohydr. Res. 172: 243-253.

PERROT, M. O.; GRILLOT, R. \& AMBROISE-THOMAS, P., 1977. Répartition dans l'organisme et sensibilité à la 5 -fluorocy tosine des deux sérotypes de Candida albicans. Etude de 680 souches. Bull Soc. Fr. Mycol. Med., 6: 305-309.

REPENTYGNY, L., 1984. Current trends in immunodiagnosis of candidiasis and aspergilosis. Rev. Infect. Dis., $6: 301-312$.

RIPPON, J. W., 1982. Medical Mycology. The Pathogenic Fungi and The Pathogenic Actinomycetes. 2nd. ed. W. B. Saunders, Co., Philadelphia.

SIQUEIRA, A. M.; RODRIGUES, M. C. \& BRAC. CIALLI, M. L., 1980. Estrutura antigênica das espécies do gênero Candida, p. 27-46. In C. S. Lacaz, Candidiases. EDUSP, São Paulo.

WALSH, T. J. \& PIZZO, P. A., 1988. Nosocomial fungal infections: a classification for hospital. acquired fungal infections and mycoses arising from endogenous flora or reactivation. $A n n$. Rev. Microbiol., 42:517-545. 